\title{
Decreased State Appropriations and their Impact on Texas Public Four- Year Higher Education Institutions Tuition Rates through Deregulated Tuition
}

\author{
Brook Redmon Dickison*
}

\begin{abstract}
* Angelo State University Department of Curriculum \& Instruction, San Angelo, TX, USA.

E-mail: bdickison@angelo.edu
\end{abstract}

\section{Article Info}

Received: April 21, 2020

Revised: May 23, 2020

Accepted: May 23, 2020

\subsection{3/repam.02.01.4}

This is an Open Access article distributed under the terms of the CC BY-NC-ND 4.0 International license.

(https://creativecommons.org/licenses/bync-nd/4.0)

\section{How to cite}

Dickison, B. R. (2020). Decreased state appropriations and their impact on Texas public four year-year higher education institutions tuition rates through deregulated tuition. Research in Educational Policy and Management, 2(1), 57-83.

https://doi.org/10.46303/repam.02.01.4

\section{ABSTRACT}

The purpose of this nonexperimental quantitative correlational study was to examine the relationships between state appropriation decreases and the deregulated tuition cost increases in Texas public four-year higher education institutions. State appropriation decreases are those decreases in the state's financial investment in higher education. Deregulated tuition is the tuition rate set by higher education institutions that is not regulated by the Texas Legislature. By studying the decreases in state appropriations and the increases in institution tuition rates, an understanding can take shape of what impact, if any, the disinvestment by state legislatures has caused to the operations of higher education institutions. Findings from this study showed no evidence of a correlation existing between the decrease in state appropriations and the increase of Texas public higher education institution tuition costs, when the analysis reviewed the timeframe from fiscal years 2003 to 2016.

\section{KEYWORDS}

State appropriations; tuition deregulation; public university. 


\section{INTRODUCTION}

American institutions of higher education are affected by downturns in the economy. A key change related to the economic environment has been the financial instability of the public university across the United States (U.S.), and specifically a focus in this study, the state of Texas's funding model for its public universities. Texas public universities are funded on a formula. The formula funding process involves the disbursement of appropriations allocated to institutions of higher education through the state (Texas Higher Education Coordinating Board [THECB], 2018). However, as the state of Texas struggles to balance the formula for funding, they provide decreasing or inconsistent funding to public higher education institutions (McPherson \& Shulenburger, 2008). The potential loss of financial consistency causes higher education administrators to look for other revenue sources to replace funds they no longer receive from the state, but also to obtain funds that they have more direct control over (e.g., tuition rates). With a reliance on alternative revenue generating activities, institutions are not always able to influence or control how much funding may be awarded from other resources, which creates instability and inconsistency in their operations (Megan \& Varn, 2017; Mitchell, Leachman, \& Masterson, 2016).

Prior to 2003, regulatory authority governed by the 78th Texas Legislature set tuition rates, mandating the same rate be charged across the state for statutory and designated tuition (THECB, 2015). In passing House Bill 3015 (HB 3015) that deregulated tuition, the state government legislatively allowed governing bodies of public higher education institutions to set a different rate of tuition (TEC $\$ 54.0513$ ), shifting tuition setting authority from the legislature to the governing board of each higher education institution (Flores \& Shepard, 2014). Prior to the 2003 passage of HB 3015, the state legislature regulated cost of attendance by imposing caps or limits on specialized fees an institution might assess on students, including designated tuition, which was not allowed to exceed an authorized rate (THECB, 2016).

After the deregulation of tuition, the increase in education costs in Texas has become a challenging situation for higher education institutions (Delaney \& Kearney, 2015; Dolan, 2015; Flores \& Shepard, 2014). According to some researchers, this increase can be directly connected to the decline in state support for higher education (e.g., Bound, Braga, Khanna, \& Turner, 2016; Conner \& Rabvsky, 2011; Russell, 2015). The decreasing state funding of public higher education is occurring at the time when colleges and universities have had a greater need for state support to cover their increased operational costs (Cobb, 2017; Hensley, 2015; Page \& Scott-Clayton, 2016; Webber, 2016). The disinvestment in higher education through state appropriation affects the formula funding process; therefore, it impacts the overall higher education operational budget due to the lack of formula funding allocations provided by the state (Bound et al., 2016; College Board, 2016). 


\section{Purpose of the Study}

The purpose of this study was to examine the relationship between state appropriation decreases and the deregulated tuition cost increases in Texas public four-year higher education institutions. State appropriation decreases are defined as a decrease in the state's financial investment of postsecondary education (National Center of State Legislatures[NCSL], 2015). Deregulated tuition is defined as the tuition rate set by higher education institutions, or rates not governed by Texas Legislature (THECB, 2010). By studying the decreases in state appropriations and the increases in institution tuition rates, an understanding takes shape of what impact, if any, the disinvestment of state legislatures regarding public higher education has on the operations of public four-year higher education institutions.

\section{REVIEW OF LITERATURE}

Cohen and Kisker (2010) offer a broad understanding that higher education was restricted to the wealthy or privileged prior to the Civil War, making it selective in nature. Bastedo, Altbach, and Gumport (2016) assert that prior to the availability of higher learning to the public, many perceived a high school education was more than sufficient to enter the workforce. The workforce in the 19th century was primarily based in trade, retail, and agriculture, and individuals predominantly learned through apprenticeships in much the same way as did their predecessors (Kasriel, 2017). A number of authors describe a small, elite group of individuals were allowed access to the higher learning environment, whose focus then was to produce male citizens within the community in areas such as the ministry, medicine, law, education, or other areas of public service (e.g., Bastedo et al. 2016; Cohen \& Kisker, 2010; Lucas, 1994). Prestigious private institutions honed the skills of future leaders through a curriculum comprised of culture, critical thinking, Latin, philosophy, and other classics of Western civilization (Bastedo et al., 2016).

\section{State Support}

The developmental stages of higher education paralleled with the developmental stages of society (Ames, 2014). The heightened focus on science and math caused an increased interest in funding for producing individuals capable of innovation. The 1958 National Defense Education Act (NDEA) emphasized the need for continued education at all levels, especially in the areas concerning national security, including but not limited to foreign languages, math, science, and technology (Ames, 2014; Cooper, 2017; Elliott \& Lewis, 2017). The NDEA encouraged a concentration in such areas emphasizing the need and desire to be competitive as a country and pushing for higher levels of enrollment (Ames, 2014).

The HEA of 1965, coupled with the fluctuation of public sentiment in the 1970s, produced a shift towards financial aid programs, which were ratified by the HEA to provide families' resources to invest in a higher education, diminishing the need for institutions to have a low 
tuition rate (Cohen \& Kisker, 2010). As this shift was made, harder questions were asked. Large consideration was taken into account with regard to contributing factors influencing the rising costs of academic offerings causing to look at basic supply and demand (Barr \& McClellan, 2011). This financial change has become more about students paying for the cost demanded of the market that is higher education. Bastedo et al. (2016) argued the low cost of tuition was inefficient as the growth in demand for a higher education persisted, reverting to an elitist mindset insinuating those who could afford the subsidized prices could attend. Through this shift in financial aid programs, the conditioning effects of the external factors saw a progression by the elitist in support of increased tuition prices.

\section{Costs of Higher Education}

The rise in the costs of tuition has caused institutions of higher education and students and their parents, increasing concern (Cornelius \& Frank, 2015). Tuition and fees remains a necessary and significant source of revenue for many institutions (Tandberg, 2013). In 2008, state funding accounted for approximately $35 \%$ of the revenue for higher education institutions' revenue where the tuition and fees were almost to $50 \%$ and auxiliary enterprise was nearly $15 \%$ (Tandberg \& Laderman, 2018). When costs are reviewed broken down like this, institutions would be financially affected by a flat or decreasing state funding formula (Texas Higher Education Coordinating Board [THECB], 2014). Tuition costs and the importance of having a higher education have increased similarly (Weeden, 2015; Weerta \& Ronca, 2012). Higher education is no longer a luxury, but a necessity to stay competitive in the job market through growth and development (U.S. Department of Education, 2017). Coates and Mahart (2015) asserted that the selectivity or competitiveness of higher education is a key component to the funding dynamic. Institutions of higher education are measured on how well they prepare students for the job market, which is the market value of education (Barr \& McClellan, 2011). Yet, the same institutions are criticized when the cost of tuition increases due to market forces (Kim \& Stange, 2016). The student's choice of institution, within affordability constraints, is even further limited (Rothstein \& Rouse, 2011).

In the face of rising costs, it is important to understand the interplay between the state legislature and governing bodies of higher education institutions. Research indicates that until 2003, Texas had a rigid legislative control over tuition rates (e.g., Weerts \& Ronca, 2012). The tuition deregulation in 2003 through House Bill 3015 (HB 3015) removed that control (Hensley, 2016). Policies, such as appropriations, financial aid, and tuition, were levers that helped legislatures hold power over the structure of higher education and its capability to meet state goals and objectives (Touthkoushian \& Shafig, 2009). Each area within the higher education structure is interconnected. Institutional control diminishes when there is a decline in any of these areas (Delaney, 2014). 


\section{Evolvement of Higher Education Costs in Texas}

Public higher education in the state of Texas is continuously and rapidly changing. The allocation of state support cannot keep pace with the rising enrollment of students (Helmcamp, 2012). The deregulation of tuition, along with the rise in enrollment, causes some higher education institutions in Texas to be unaffordable and inaccessible (Shelby, 2015). This escalation of cost forces many students to assume substantial debt or some to forgo obtaining higher education altogether (Delaney \& Kearney, 2015).

Texas has relied heavily on state appropriations as a main source of funding for higher education institutions (Dougherty \& Reddy, 2010). Several researchers investigated the state context in relation to the pricing of higher education (e.g., Flores \& Shepherd, 2014; Hung, 2015; McBain, 2010; Schwertner, 2014; Titus, 2009) and found that state appropriations have historically been the most important revenue sources for higher education, but have waned over the past two decades. According to McLendon, Hearn, and Mokher (2009), a decline in state support is followed by in-state tuition increases as a result of the adverse effects during the rise in demand for higher education. Some institutions try to generate additional revenue sources to counter act the economic cycles that impact the revenue the state can generate (Dickeson, 2006). Toutkoushian and Hillman (2012) contend a connection of higher state appropriation per student are directly associated with a lesser tuition rate, though it is beyond the elasticity of the demand.

The infrastructure formula support offers funding for outside or indirect costs related to instruction and administration (Texas Legislature 80th Regular Session- HB 1, 2007). The infrastructure costs center on facilities maintenance and upkeep, such as custodial services, facilities and grounds maintenance, construction and planning, and utilities. The formula for funding structure is based on an all funds approach where general revenue is collected by the State, and statutory tuition is collected by the institution (THECB, 2015).

Formula funded allocations for infrastructure support operations and maintenance costs are associated with an institution's utilities and physical plant (Texas Legislature 84th Regular Session- HB 1, 2016). The THECB Space Projection Model (2016) allows for a prediction of space needs for an institution, categorized as teaching, library, research, and office spaces, where an allocation can be set for general institution and educational activities. The categories' assessments are determined by expenditures such as student level, faculty and staff equivalents for full-time, and research (LBB, 2016). The formula functions as it relates to the prediction of square feet, with the allocated funds assigned based on the need. House Bill 1, the General Appropriations Act for 2018-2019 Biennium, estimated this amount of funding at $\$ 5.86$ for predicted square foot, which is down from the General Appropriations Act for 2008-2009 estimating the cost at $\$ 6.19$ (Texas Legislature 80th Regular Session- HB 1, 2007). 


\section{Pre-deregulated Tuition in Texas}

Prior to September of 2003 , the Texas state legislature regulated tuition and was the primary authorization on whether tuition was increased or decreased (Tex. Educ. Code $§ 54.0513)$. The state was able to maintain relatively low tuition rates at each public institution by subsidizing the cost through appropriations (Texas Legislator- HB 3015, n.d.), as well as allocated general revenue appropriations through a formula distributed by the Legislature by the LBB (2011).

The funding model for public universities implemented in Texas produces general revenue allocations that subsidize the cost of instruction, and are designed to maintain low levels of direct cost to the student by strictly regulating tuition prices (Edwards \& McCluskey, 2015). Due to the aftermath of the Great Recession, which took place in late 2007 to mid-2009 and was defined as a devastating economic downturn since the Great Depression (Economic Policy Institute, 2017), the state of Texas announced agencies of the state, including public higher education entities, would be required to enforce a retroactive $7 \%$ reduction in overall general appropriations and return money to the state (LBB, 2016). This mandatory reduction of the general support from the state was to be fixated on administrative costs to minimize the effects on direct student services (Helmcamp, 2012). Higher education institutions were required to maintain instructional capacity, while reducing administrative operating costs. The retroactive reduction and imposition to maintain at a lower cost resulted in an unsustainable and harsh decline of resources for student support (Johnstone, 2005). The outcome led to the state legislature's determination to deregulate tuition (Watkins \& Daniels, 2017).

\section{Deregulation of Tuition in Texas}

State and higher education leaders determined that the elasticity in pricing through the deregulation of tuition would help resolve certain aspects of the funding crisis caused by the mandate of the state to return already allocated funds, by transferring higher education access into a commodity subject to market factors (Johnstone, 2005). Patrons would evaluate specific desires and determine if the overall product was what they wanted and/or needed. Flexibility with tuition would raise student access to an education by delivering additional resources to an otherwise financially struggling industry (Center for American Progress, 2018). Through the passing of HB 3015, the Legislature removed the ceiling on tuition costs (Cardona, 2012). The HB 3015 offered a solution to help public institutions to recover loss of revenue from the budget cap, which only caused to further the unfocused and insufficient downward spiral of fiscal responsibility (Jacobson, 2017). The LBB (2016) asserted downward spiral after the deregulation of tuition in Texas contributed to the surge of tuition and fee rates for Texas institutions, which increased $112 \%$ between $2003-2014$.

Designated tuition is the representation of deregulated portions of tuition that may be established by higher education institutions at a rate "that the governing board considers necessary for the effective operations of the institution" (Tex. Educ. Code $\S 54.0513$, para. a). This sets no upper limit on the amount of designated tuition a university could change and the 
amounts might fluctuate per program, course or academic period (THECB, 2016). The designated tuition thought it is a form of outside appropriations it is not processed through the suggested formula (THECB, 2018). The formula funding advisory committee and the THECB conduct a study of cost, requiring each public higher education institution to participate through the submission of a cost break down of instruction by discipline. This cost study is the basis for future recommendations towards the formula funding process to the State Legislature (THECB, 2017).

\section{Post-deregulated Tuition in Texas}

House Bill 3015 was approved to partially recoup revenues lost from state appropriations reduction in the state of Texas (Hernandez, 2008). The deregulation efforts were executed because it was perceived that the regulated system of tuition rates misrepresented the educational value, and was a causative factor of the status quo student's needs and developmental rate (Hart, 2005). Advocating for a deregulated tuition environment allowed institutional governing boards flexibility to determine the direct cost to students, and offer the ability to maximize resources and efficiency through their own assessments instruments (Kim \& Stange, 2016). Many institutions took advantage of the flexibility, accelerating prices and adopting alternative structures of pricing mirroring national differential pricing trends (College Board, 2018).

Tuition deregulation in Texas has resulted in an unprecedented increase in cost for students attending higher education institutions between 2003 and 2016 . This growth of higher education cost inflation rates has risen at an alarming rate exceeding that of tuition and fees nationally (Finney, 2016). Continued allocated subsidy reductions to institutions of higher learning impact the potential costs to students in an attempt to support escalating costs (Schwertner, 2009). The state-wide tuition rate average has rapidly increased in Texas, to such that it exceeds the national average by nearly double (College Board, 2017).

\section{Higher Education Policy in Texas}

An issue that affects the cost of higher education is the growing population in Texas, which is causing an overall increase in state spending (Gale, Krupkin, \& Rueben, 2015). Population increases are shown to correlate with an increase in higher education institutional student enrollment (Cardona, 2012). Texas lawmakers lifted restrictions on tuition rates in an effort to offset the decline in state support, which has resulted in fluctuating tuition levels (Titus, 2009). It is important to note that more students enrolled at an institution do not necessarily result in more tuition revenue. Cost of maintenance when the student population increases can strain institutional resources and overall operations (Megan, Akabas, \&Varn, 2017). As a result, Texas students are undermined as an unintended consequence of tuition deregulation (Hung, 2015). The increasing operating costs caused by increased enrollments hinder the ability to provide 
accessible and affordable education for students attending higher education institutions, especially in Texas (Dolan, 2015).

Higher education and legislative action have maintained an inverse relationship. This can be traced through the groundwork of many policies, from the Morrill Act (1862) to the HEA (1965) to the General Appropriations Act (1949), highlighting the vital role of the federal government in the higher education arena (Altbach et al., 2011). With creation of these policies by the Legislature, higher education is able to offer a benefit to society through the preparation of students, engaged applicable experiences, and the cultivation of necessary skills for the workforce (Alfred, 2006). Factors contributing to the demand of educated workforce and the changing economy are turbulent in nature, creating a relationship of tension between higher education and legislative actions as it pertains to tuition costs or higher education affordability (Cohen \& Kisker, 2010).

\section{THEORETICAL FRAMEWORK OF THE STUDY}

This study was framed by resource dependence theory. Resource dependence theory explains how organizations react to external factors (Pfeffer \& Salancik, 1978, 2003). The theory can be used to explain how organizational behavior changes as external factors, such as in the case of this study the decrease in state appropriations, affects institutional behavior relative to how the decrease in funds is addressed. As supported by systems theory, public higher education institutions are dependent on their environments for resources (Bess \& Dee, 2008). Institutions must react to changes in their environment in order to survive. For public four-year higher education institutions in the state of Texas, that reaction has occurred relative to state funding for decades, but more so after the deregulation of tuition in Texas in 2003. ipsum dolor sit amet, consectetur adipiscing elit. Etiam et rhoncus massa, quis lobortis dui. Suspendisse nisi lorem, suscipit at massa non, tincidunt efficitur lectus. Sed finibus tempor enim a convallis. Donec hendrerit hendrerit enim, non pretium felis faucibus eget. Nunc non cursus dui. Suspendisse maximus felis ac scelerisque fringilla. Quisque at ante nec nulla sagittis tristique ac venenatis tellus. Ut posuere sed augue eget mollis. In sodales porttitor enim, ut ullamcorper sapien tristique ac. Vestibulum ornare fringilla augue quis luctus. Nunc pulvinar nisi turpis, accumsan vulputate eros posuere vitae. Quisque diam nunc, molestie sed nisl sed, euismod malesuada ligula. Orci varius natoque penatibus et magnis dis parturient montes, nascetur ridiculus mus.

\section{METHODOLOGY}

A nonexperimental quantitative correlation study was designed to examine the relationship between state appropriation decreases and the deregulated tuition cost related increases in Texas four-year, public higher education tuition rates. The study population was the 34 Texas public four-year universities. This study utilized secondary data housed in the IPEDS database. Data collected focused on data from the point of tuition deregulation in 2003 through 2016 used 
for this study. Data analyses that were conducted through the use of correlation coefficients leading to a show of potential strength or a degree in the relationship through a measure of two or more variables. The IPEDS generates a standard performance edit check for each institution's review that provides the ability for each institution to resolve errors through the system before the data is locked into the system database. This helps to ensure the data provided are valid and reliable for this study.

Table 1: Texas Public Four-Year Universities Offering Bachelor Degrees and Their Geographic Locations

\begin{tabular}{|c|c|}
\hline Institution Name & Location \\
\hline Angelo State University & San Angelo, Texas \\
\hline Lamar University & Beaumont, Texas \\
\hline Midwestern State University & Wichita Falls, Texas \\
\hline Prairie View A\&M University & Prairie View, Texas \\
\hline Sam Houston State University & Huntsville, Texas \\
\hline Stephen F. Austin State University & Nacogdoches, Texas \\
\hline Sul Ross State University & Alpine, Texas \\
\hline Tarleton State University & Stephenville, Texas \\
\hline Texas A\&M International University & Laredo, Texas \\
\hline Texas A\&M University & College Station, Texas \\
\hline Texas A\&M University-Commerce & Commerce, Texas \\
\hline Texas A\&M University-Corpus Christi & Corpus Christi, Texas \\
\hline Texas A\&M University- Kingsville & Kingsville, Texas \\
\hline Texas A\&M University-San Antonio & San Antonio, Texas \\
\hline Texas A\&M University-Texarkana & Texarkana, Texas \\
\hline Texas Southern University & Houston, Texas \\
\hline Texas State University & San Marcos, Texas \\
\hline Texas Tech University & Lubbock, Texas \\
\hline Texas Woman's University & Denton, Texas \\
\hline The University of Texas at Arlington & Arlington, Texas \\
\hline The University of Texas & Austin, Texas \\
\hline The University of Texas at Dallas & Dallas, Texas \\
\hline The University of Texas at El Paso & El Paso, Texas \\
\hline The University of Texas at San Antonio & San Antonio, Texas \\
\hline The University of Texas at Tyler & Tyler, Texas \\
\hline The University of Texas at the Permian Basin & Odessa, Texas \\
\hline The University of Texas Rio Grande Valley & Edinburg, Texas \\
\hline University of Houston & Houston, Texas \\
\hline University of Houston- Clear Lake & Houston, Texas \\
\hline University of Houston-Downtown & Houston, Texas \\
\hline University of Houston -Victoria & Victoria, Texas \\
\hline University of North Texas & Denton, Texas \\
\hline University of North Texas at Dallas & Dallas, Texas \\
\hline West Texas A\&M University & Canyon, Texas \\
\hline \multicolumn{2}{|c|}{ Note: Adapted from Texas Higher Education Coordinating Board. Institutions and Researchers. List of } \\
\hline Institutions. Retrieved from http://www.txhig & ctive/Institutions.cfm \\
\hline
\end{tabular}


The dataset was then sorted to group the study institutions by size according to their designated Carnegie Foundation (n.d.) classifications. See Table 2 for a list of institutions by institutional size.

Table 2: Texas Public Four-year Higher Education Institutions by Institution Size

\begin{tabular}{ll}
\hline Institutions & Institution Size \\
\hline Angelo State University & Medium \\
Lamar University & Large \\
Midwestern State University & Medium \\
Prairie View A \& M University & Medium \\
Sam Houston State University & Very Large \\
Stephen F Austin State University & Large \\
Sul Ross State University & Small \\
Tarleton State University & Large \\
Texas A \& M International University & Medium \\
Texas A \& M University-College Station & Very Large \\
Texas A \& M University-Commerce & Large \\
Texas A \& M University-Corpus Christi & Large \\
Texas A \& M University-Kingsville & Medium \\
Texas A \& M University-Texarkana & Small \\
Texas Southern University & Medium \\
Texas State University & Very Large \\
Texas Tech University & Very Large \\
Texas Women's University & Large \\
The University of Texas at Arlington & Very Large \\
The University of Texas at Austin & Very Large \\
The University of Texas at Dallas & Very Large \\
The University of Texas at El Paso & Very Large \\
The University of Texas at San Antonio & Very Large \\
The University of Texas at Tyler & Medium \\
The University of Texas of the Permian Basin & Medium \\
The University of Texas Rio Grande Valley & Very Large \\
University of Houston & Very Large \\
University of Houston-Clear Lake & Medium \\
University of Houston-Downtown & Large \\
University of Houston-Victoria & Small \\
University of North Texas & Very Large \\
West Texas A \& M University & Medium \\
\hline & \\
\hline &
\end{tabular}

Table 3 presents the state appropriations per full-time equivalent (FTE) student for FY 2003 to FY 2016 for each of the 32 Texas public four-year higher education institutions as well as tuition and fees per FTE student for this same time period 
Table 3: Characteristics of Sample

\begin{tabular}{|c|c|c|c|}
\hline Variable & $\mathbf{M}$ & $\begin{array}{c}\text { Std. } \\
\text { Deviation }\end{array}$ & Std. Error \\
\hline \multicolumn{4}{|l|}{ Sul Ross State University } \\
\hline State Appropriations Per FTE Student & $10,079.00$ & 876.00 & 234.00 \\
\hline Tuition and Fees Per FTE Student & $3,481.00$ & $1,230.00$ & 329.00 \\
\hline \multicolumn{4}{|l|}{ Texas A \& M University-Texarkana } \\
\hline State Appropriations Per FTE Student & $12,301.00$ & $2,136.00$ & 571.00 \\
\hline Tuition and Fees Per FTE Student & $3,906.00$ & $1,207.00$ & 322.70 \\
\hline \multicolumn{4}{|l|}{ University of Houston-Victoria } \\
\hline State Appropriations Per FTE Student & $7,221.00$ & $1,289.00$ & 344.00 \\
\hline Tuition and Fees Per FTE Student & $5,079.00$ & 758.00 & 202.55 \\
\hline \multicolumn{4}{|l|}{ Angelo State University } \\
\hline State Appropriations Per FTE Student & $5,415.00$ & 468.00 & 125.00 \\
\hline Tuition and Fees Per FTE Student & $5,015.00$ & $1,431.00$ & 382.58 \\
\hline \multicolumn{4}{|l|}{ Midwestern State University } \\
\hline State Appropriations Per FTE Student & $4,291.00$ & 296.00 & 79.00 \\
\hline Tuition and Fees Per FTE Student & $5,042.00$ & $1,230.00$ & 328.73 \\
\hline \multicolumn{4}{|l|}{ Prairie View A \& M University } \\
\hline State Appropriations Per FTE Student & $7,729.00$ & 673.00 & 180.00 \\
\hline Tuition and Fees Per FTE Student & $4,439.00$ & $1,112.00$ & 297.24 \\
\hline \multicolumn{4}{|l|}{ Texas A \& M International University } \\
\hline State Appropriations Per FTE Student & $8,454.00$ & $1,911.00$ & 511.00 \\
\hline Tuition and Fees Per FTE Student & $3,049.00$ & 973.00 & 260.16 \\
\hline \multicolumn{4}{|l|}{ Texas A \& M University-Kingsville } \\
\hline State Appropriations Per FTE Student & $6,617.00$ & $1,032.00$ & 276.00 \\
\hline Tuition and Fees Per FTE Student & $4,748.00$ & $1,364.00$ & 364.57 \\
\hline \multicolumn{4}{|l|}{ Texas Southern University } \\
\hline State Appropriations Per FTE Student & $9,359.00$ & $4,650.00$ & $1,243.00$ \\
\hline Tuition and Fees Per FTE Student & $6,825.00$ & $2,588.00$ & 691.70 \\
\hline \multicolumn{4}{|l|}{ The University of Texas at Tyler } \\
\hline State Appropriations Per FTE Student & $6,345.00$ & 705.00 & 189.00 \\
\hline Tuition and Fees Per FTE Student & $4,283.00$ & $1,197.00$ & 319.95 \\
\hline \multicolumn{4}{|c|}{ The University of Texas of the Permian Basin } \\
\hline State Appropriations Per FTE Student & $8,178.00$ & $2,247.00$ & 601.00 \\
\hline Tuition and Fees Per FTE Student & $3,842.00$ & $1,303.00$ & 348.33 \\
\hline \multicolumn{4}{|l|}{ University of Houston-Clear Lake } \\
\hline State Appropriations Per FTE Student & $5,700.00$ & 619.00 & 166.00 \\
\hline Tuition and Fees Per FTE Student & $5,295.00$ & $1,858.00$ & 496.54 \\
\hline
\end{tabular}


West Texas A \& M University

State Appropriations Per FTE Student

Tuition and Fees Per FTE Student

Lamar University

State Appropriations Per FTE Student

Tuition and Fees Per FTE Student

Stephen F Austin State University

State Appropriations Per FTE Student

Tuition and Fees Per FTE Student

Tarleton State University

State Appropriations Per FTE Student

Tuition and Fees Per FTE Student

Texas A \& M University-Commerce

State Appropriations Per FTE Student

Tuition and Fees Per FTE Student

Texas A \& M University-Corpus Christi

State Appropriations Per FTE Student

Tuition and Fees Per FTE Student

Texas Women's University

State Appropriations Per FTE Student

Tuition and Fees Per FTE Student

University of Houston-Downtown

State Appropriations Per FTE Student

Tuition and Fees Per FTE Student

Sam Houston State University

State Appropriations Per FTE Student

Tuition and Fees Per FTE Student

Texas A \& M University-College Station State Appropriations Per FTE Student Tuition and Fees Per FTE Student

Texas State University

State Appropriations Per FTE Student Tuition and Fees Per FTE Student

Texas Tech University

State Appropriations Per FTE Student Tuition and Fees Per FTE Student

The University of Texas at Arlington

State Appropriations Per FTE Student

Tuition and Fees Per FTE Student
$5,140.00$

642.00

171.00

$4,629.00$

$1,318.00$

352.25

$4,280.00$

580.00

155.00

$5,933.00$

$1,601.00$

427.80

$4,588.00$

288.00

$1,510.00$

77.00

$5,015.00$

$4,809.00$

690.00

$1,255.00$

185.00

$4,825.00$

$5,208.00$

410.00

110.00

$5,482.00$

$1,631.00$

$7,034.00$

$5,172.00$

779.00

208.00

$1,601.00$

427.76

$5,775.00$

$5,283.00$

802.00

214.00

626.00

167.23

$3,115.00$

473.00

126.00

$4,772.00$

$1,349.00$

434.00

$1,536.00$

116.00

$3,556.00$

$5,511.00$

$10,315.00$

1,099

1,935

294.00

517.11

$7,639.00$

$4,377.00$

370.00

99.00

$5,920.00$

$1,343.00$

$5,541.00$

392.00

105.00

$7,574.00$

$1,335.00$

695.00

186.00

$4,420.00$

$1,228.00$

328.20 
The University of Texas at Austin

State Appropriations Per FTE Student

$\begin{array}{rrr}6,603.00 & 590.00 & 158.00 \\ 8,618.00 & 1,823.00 & 487.26\end{array}$

Tuition and Fees Per FTE Student

487.26

The University of Texas at Dallas

State Appropriations Per FTE Student

$5,721.00$

649.00

174.00

Tuition and Fees Per FTE Student

$8,168.00$

$2,518.00$

672.87

The University of Texas at El Paso

State Appropriations Per FTE Student

$5,176.00$

442.00

118.00

Tuition and Fees Per FTE Student

$4,754.00$

$1,045.00$

279.24

The University of Texas at San Antonio

State Appropriations Per FTE Student

$4,563.00$

455.00

122.00

Tuition and Fees Per FTE Student

$6,378.00$

$1,407.00$

376.17

The University of Texas Rio Grande Valley

State Appropriations Per FTE Student

Tuition and Fees Per FTE Student

$4,611.00$

615.00

164.00

3.06

737.00

197.01

University of Houston

State Appropriations Per FTE Student

Tuition and Fees Per FTE Student

539.00

144.00

$7,846.00$

$1,920.00$

513.07

University of North Texas

State Appropriations Per FTE Student

$4,213.00$

349.00

93.00

Tuition and Fees Per FTE Student

$6,420.00$

$1,708.00$

456.56

Table 4 presents the state appropriations per full-time equivalent (FTE) student for FY 2003 to FY 2016 for each of the 32 Texas public four-year higher education institutions as well as tuition and fees per FTE student for this same time period. 
Table 4: State Appropriations per FTE Student for FY 2003 to FY 2016 by Institutional Size

\begin{tabular}{|c|c|c|c|c|c|c|c|c|c|c|c|c|c|c|c|}
\hline Institution Name & Size & 2003 & 2004 & 2005 & 2006 & 2007 & 2008 & 2009 & 2010 & 2011 & 2012 & 2013 & 2014 & 2015 & 2016 \\
\hline $\begin{array}{l}\text { Sul Ross State } \\
\text { University }\end{array}$ & 2 & 8,653 & 9,134 & 9,603 & 9,840 & 10,279 & 11,149 & 10,785 & 9,944 & 9,619 & 11,891 & 10,152 & 10,709 & 10,319 & 9,026 \\
\hline $\begin{array}{l}\text { Texas A\&M University- } \\
\text { Texarkana }\end{array}$ & 2 & 9,064 & 9,830 & 9,936 & 10,449 & 10,173 & 15,022 & 15,058 & 13,689 & 12,178 & 11,512 & 13,007 & 13,659 & 13,566 & 15,067 \\
\hline $\begin{array}{l}\text { University of Houston- } \\
\text { Victoria }\end{array}$ & 2 & 7,686 & 8,055 & 8,241 & 8,338 & 7,844 & 9,802 & 8,094 & 7,361 & 6,414 & 5,587 & 5,454 & 5,933 & 5,882 & 6,401 \\
\hline $\begin{array}{l}\text { Angelo State } \\
\text { University }\end{array}$ & 3 & 5,286 & 6,249 & 5,839 & 5,342 & 5,543 & 5,786 & 5,560 & 5,415 & 4,940 & 4,539 & 4,780 & 5,847 & 5,642 & 5,044 \\
\hline $\begin{array}{l}\text { Midwestern State } \\
\text { University }\end{array}$ & 3 & 3,780 & 3,794 & 3,920 & 4,282 & 4,443 & 4,567 & 4,568 & 4,421 & 4,332 & 4,049 & 4,317 & 4,434 & 4,428 & 4,736 \\
\hline $\begin{array}{l}\text { Prairie View A\&M } \\
\text { University }\end{array}$ & 3 & 6,879 & 7,886 & 8,139 & 8,681 & 8,280 & 8,680 & 8,391 & 7,911 & 7,932 & 7,171 & 6,969 & 6,933 & 6,845 & 7,504 \\
\hline $\begin{array}{l}\text { Texas A\&M } \\
\text { International } \\
\text { University }\end{array}$ & 3 & 10,154 & 10,660 & 10,326 & 10,335 & 9,579 & 10,694 & 9,714 & 8,108 & 7,290 & 6,409 & 6,362 & 6,377 & 6,059 & 6,284 \\
\hline $\begin{array}{l}\text { Texas A\&M University- } \\
\text { Kingsville }\end{array}$ & 3 & 5,251 & 6,742 & 7,401 & 7,740 & 7,293 & 8,378 & 7,890 & 7,105 & 6,256 & 5,918 & 5,423 & 6,038 & 5,270 & 5,931 \\
\hline $\begin{array}{l}\text { Texas Southern } \\
\text { University }\end{array}$ & 3 & 4,902 & 5,108 & 6,113 & 10,890 & 11,718 & 16,923 & 19,131 & 15,076 & 7,332 & 6,148 & 6,306 & 6,521 & 7,322 & 7,536 \\
\hline $\begin{array}{l}\text { The University of } \\
\text { Texas at Tyler }\end{array}$ & 3 & 5,745 & 6,895 & 6,562 & 6,474 & 6,348 & 7,301 & 7,565 & 7,283 & 6,293 & 5,791 & 5,513 & 6,008 & 5,541 & 5,510 \\
\hline $\begin{array}{l}\text { The University of } \\
\text { Texas of the Permian } \\
\text { Basin }\end{array}$ & 3 & 4,832 & 6,526 & 5,999 & 6,287 & 5,751 & 11,395 & 11,952 & 11,057 & 8,603 & 9,722 & 9,163 & 8,208 & 7,220 & 7,774 \\
\hline $\begin{array}{l}\text { University of Houston- } \\
\text { Clear Lake }\end{array}$ & 3 & 4,939 & 5,604 & 5,753 & 6,059 & 6,109 & 6,545 & 6,654 & 6,387 & 6,043 & 4,977 & 4,996 & 5,265 & 4,885 & 5,585 \\
\hline $\begin{array}{l}\text { West Texas A\&M } \\
\text { University }\end{array}$ & 3 & 3,766 & 4,963 & 5,341 & 5,517 & 5,569 & 6,065 & 6,014 & 5,793 & 5,285 & 4,819 & 4,740 & 4,588 & 4,496 & 5,010 \\
\hline Lamar University & 4 & 4,400 & 5,108 & 4,669 & 4,785 & 5,111 & 4,280 & 3,756 & 4,580 & 4,466 & 4,075 & 3,361 & 3,440 & 3,516 & 4,369 \\
\hline
\end{tabular}




\begin{tabular}{|c|c|c|c|c|c|c|c|c|c|c|c|c|c|c|c|}
\hline $\begin{array}{l}\text { Stephen F Austin State } \\
\text { University }\end{array}$ & 4 & 4,111 & 4,374 & 4,621 & 4,640 & 4,580 & 5,226 & 4,899 & 4,824 & 4,523 & 4,225 & 4,282 & 4,659 & 4,614 & 4,660 \\
\hline $\begin{array}{l}\text { Tarleton State } \\
\text { University }\end{array}$ & 4 & 3,717 & 4,266 & 4,596 & 4,762 & 4,660 & 5,910 & 5,799 & 5,849 & 5,367 & 5,041 & 4,073 & 4,470 & 4,296 & 4,523 \\
\hline $\begin{array}{l}\text { Texas A\&M University- } \\
\text { Commerce }\end{array}$ & 4 & 4,545 & 5,191 & 5,268 & 5,341 & 5,292 & 5,910 & 5,983 & 5,359 & 5,164 & 4,731 & 4,654 & 5,359 & 5,079 & 5,042 \\
\hline $\begin{array}{l}\text { Texas A\&M University- } \\
\text { Corpus Christi }\end{array}$ & 4 & 6,260 & 7,233 & 7,484 & 7,589 & 7,312 & 8,409 & 8,046 & 7,851 & 6,919 & 6,238 & 5,986 & 6,322 & 6,246 & 6,581 \\
\hline $\begin{array}{l}\text { Texas Women's } \\
\text { University }\end{array}$ & 4 & 5,426 & 6,603 & 5,838 & 6,969 & 6,760 & 6,595 & 6,626 & 5,751 & 5,608 & 4,825 & 4,592 & 5,033 & 5,145 & 5,083 \\
\hline $\begin{array}{l}\text { University of Houston- } \\
\text { Downtown }\end{array}$ & 4 & 3,005 & 2,988 & 2,931 & 3,360 & 3,478 & 3,809 & 3,761 & 3,604 & 3,565 & 2,582 & 2,422 & 2,673 & 2,579 & 2,856 \\
\hline $\begin{array}{l}\text { Sam Houston } \\
\text { StateUniversity }\end{array}$ & 5 & 3,132 & 4,128 & 4,283 & 3,897 & 3,460 & 3,774 & 3,774 & 3,727 & 3,180 & 2,825 & 3,091 & 3,283 & 3,310 & 3,920 \\
\hline Texas A\&M University & 5 & 7,979 & 9,814 & 9,820 & 9,880 & 9,965 & 10,717 & 10,526 & 10,398 & 10,249 & 9,655 & 9,570 & 12,080 & 11,553 & 12,206 \\
\hline Texas State University & 5 & 3,751 & 4,216 & 4,416 & 4,449 & 4,342 & 5,036 & 4,853 & 4,566 & 4,468 & 3,683 & 4,150 & 4,361 & 4,282 & 4,702 \\
\hline Texas Tech University & 5 & 5,238 & 4,962 & 4,981 & 5,454 & 5,660 & 6,360 & 5,965 & 5,737 & 5,526 & 5,351 & 5,146 & 5,818 & 5,567 & 5,814 \\
\hline $\begin{array}{l}\text { The University of } \\
\text { Texas at Arlington }\end{array}$ & 5 & 4,292 & 4,678 & 4,506 & 5,016 & 5,059 & 5,557 & 5,523 & 4,605 & 3,742 & 4,099 & 4,024 & 3,853 & 3,415 & 3,508 \\
\hline $\begin{array}{l}\text { The University of } \\
\text { Texas at Austin }\end{array}$ & 5 & 5,494 & 5,937 & 6,186 & 6,517 & 6,484 & 7,127 & 7,353 & 7,156 & 6,537 & 6,255 & 6,184 & 6,653 & 6,891 & 7,662 \\
\hline $\begin{array}{l}\text { The University of } \\
\text { Texas at Dallas }\end{array}$ & 5 & 5,435 & 5,803 & 5,797 & 5,941 & 5,972 & 6,791 & 6,526 & 6,730 & 5,727 & 5,440 & 5,019 & 5,325 & 4,860 & 4,723 \\
\hline $\begin{array}{l}\text { The University of } \\
\text { Texas at El Paso }\end{array}$ & 5 & 4,437 & 4,791 & 4,815 & 5,210 & 5,142 & 5,734 & 5,816 & 5,732 & 4,833 & 4,777 & 5,040 & 4,962 & 5,562 & 5,617 \\
\hline $\begin{array}{l}\text { The University of } \\
\text { Texas at San Antonio }\end{array}$ & 5 & 3,765 & 3,943 & 4,174 & 4,423 & 4,318 & 4,996 & 4,984 & 5,048 & 4,488 & 4,259 & 4,385 & 5,051 & 5,173 & 4,875 \\
\hline $\begin{array}{l}\text { The University of } \\
\text { Texas Rio Grande } \\
\text { Valley }\end{array}$ & 5 & 4,203 & 4,639 & 4,840 & 4,991 & 4,884 & 4,766 & 4,790 & 4,586 & 4,155 & 4,078 & 4,087 & 4,177 & 3,993 & 6,369 \\
\hline University of Houston & 5 & 5,046 & 5,291 & 5,536 & 5,521 & 6,094 & 6,609 & 6,211 & 5,939 & 5,452 & 4,789 & 4,784 & 5,329 & 5,111 & 5,301 \\
\hline $\begin{array}{l}\text { University of North } \\
\text { Texas }\end{array}$ & 5 & 4,973 & 4,350 & 3,512 & 4,240 & 4,174 & 4,389 & 4,559 & 4,184 & 4,262 & 3,902 & 3,747 & 4,285 & 4,294 & 4,115 \\
\hline
\end{tabular}


Table 5: Revenue from Tuition and Fees per FTE Student for FY 2003 to FY 2016 by Institutional Size

\begin{tabular}{|c|c|c|c|c|c|c|c|c|c|c|c|c|c|c|c|}
\hline Institution Name & Size & 2003 & 2004 & 2005 & 2006 & 2007 & 2008 & 2009 & 2010 & 2011 & 2012 & 2013 & 2014 & 2015 & 2016 \\
\hline Sul Ross State University & 2 & 1,603 & 2,194 & 2,603 & 2,624 & 2,919 & 3,053 & 3,059 & 3,137 & 5,060 & 5,434 & 5,807 & 4,104 & 3,737 & 3,400 \\
\hline Texas A\&M University-Texarkana & 2 & 3,236 & 3,685 & 2,864 & 1,781 & 2,831 & 2,774 & 3,306 & 4,139 & 3,987 & 4,397 & 5,426 & 4,813 & 5,827 & 5,618 \\
\hline University of Houston-Victoria & 2 & 3,441 & 4,060 & 4,286 & 4,429 & 4,959 & 5,602 & 5,658 & 5,335 & 5,080 & 5,509 & 5,219 & 5,675 & 5,948 & 5,910 \\
\hline Angelo State University & 3 & 2,839 & 3,180 & 3,286 & 3,375 & 4,104 & 4,803 & 5,116 & 5,000 & 6,080 & 6,478 & 6,454 & 6,349 & 6,523 & 6,619 \\
\hline Midwestern State University & 3 & 2,920 & 3,349 & 3,780 & 4,120 & 4,190 & 4,837 & 5,118 & 5,051 & 5,682 & 5,618 & 6,401 & 6,322 & 6,518 & 6,678 \\
\hline Prairie View A\&M University & 3 & 2,139 & 2,946 & 3,079 & 3,659 & 4,352 & 4,695 & 4,483 & 4,702 & 4,615 & 5,675 & 5,137 & 5,322 & 5,901 & 5,437 \\
\hline Texas A\&M International University & 3 & 1,126 & 1,362 & 2,154 & 2,199 & 2,765 & 3,481 & 3,801 & 3,354 & 3,445 & 3,351 & 3,700 & 3,799 & 4,080 & 4,063 \\
\hline Texas A\&M University-Kingsville & 3 & 3,001 & 3,129 & 3,251 & 3,696 & 3,991 & 4,314 & 4,466 & 4,683 & 4,715 & 5,194 & 5,669 & 6,090 & 6,996 & 7,282 \\
\hline Texas Southern University & 3 & 2,113 & 3,235 & 3,902 & 7,224 & 7,757 & 9,345 & 9,457 & 11,976 & 6,522 & 6,124 & 6,770 & 5,996 & 7,220 & 7,909 \\
\hline The University of Texas at Tyler & 3 & 2,062 & 2,766 & 2,845 & 3,386 & 4,014 & 4,161 & 4,895 & 4,177 & 4,626 & 4,686 & 4,739 & 5,699 & 5,933 & 5,967 \\
\hline The University of Texas of the & 3 & 2,249 & 2,233 & 3,132 & 3,229 & 2,719 & 3,651 & 3,577 & 4,934 & 3,026 & 3,575 & 5,242 & 6,767 & 4,142 & 5,316 \\
\hline \multicolumn{16}{|l|}{ Permian Basin } \\
\hline University of Houston-Clear Lake & 3 & 3,353 & 4,513 & 4,939 & 5,474 & 5,872 & 6,315 & 7,036 & 6,775 & 7,029 & 7,425 & 7,544 & 9,069 & 9,401 & 9,718 \\
\hline West Texas A\&M University & 3 & 2,341 & 3,095 & 3,466 & 3,724 & 3,794 & 4,477 & 4,387 & 4,388 & 4,689 & 5,378 & 5,769 & 6,029 & 6,369 & 6,897 \\
\hline Lamar University & 4 & 2,369 & 3,834 & 4,400 & 4,752 & 5,708 & 6,141 & 5,541 & 7,028 & 7,282 & 7,037 & 6,771 & 6,651 & 7,771 & 7,770 \\
\hline Stephen F Austin State University & 4 & 2,821 & 2,956 & 3,111 & 3,696 & 4,047 & 5,390 & 5,273 & 5,023 & 5,369 & 5,556 & 5,908 & 6,311 & 7,222 & 7,524 \\
\hline Tarleton State University & 4 & 2,896 & 2,977 & 3,717 & 3,788 & 4,129 & 4,543 & 4,746 & 4,870 & 5,019 & 5,474 & 5,831 & 6,117 & 6,483 & 6,964 \\
\hline Texas A \& M University-Commerce & 4 & 2,968 & 3,261 & 3,545 & 4,252 & 4,632 & 5,222 & 5,033 & 5,177 & 6,317 & 6,877 & 7,721 & 7,175 & 7,241 & 7,320 \\
\hline Texas A \& M University-Corpus Christi & 4 & 2,684 & 2,719 & 3,260 & 4,093 & 4,458 & 4,908 & 4,883 & 5,317 & 5,686 & 6,335 & 6,678 & 6,793 & 7,143 & 7,451 \\
\hline Texas Women's University & 4 & 4,038 & 4,135 & 5,026 & 5,322 & 5,496 & 5,055 & 5,218 & 5,220 & 5,444 & 5,843 & 5,374 & 5,487 & 5,879 & 6,425 \\
\hline University of Houston-Downtown & 4 & 2,931 & 3,159 & 3,005 & 3,439 & 4,172 & 4,464 & 4,508 & 4,533 & 5,264 & 5,874 & 6,072 & 5,906 & 6,598 & 6,876 \\
\hline Sam Houston State University & 5 & 2,783 & 3,763 & 4,132 & 4,914 & 4,668 & 4,834 & 5,212 & 5,340 & 5,398 & 6,098 & 7,143 & 7,273 & 7,692 & 7,906 \\
\hline Texas A\&M University-College Station & 5 & 3,620 & 5,371 & 5,979 & 6,062 & 6,739 & 7,286 & 7,698 & 7,866 & 8,296 & 9,120 & 8,988 & 9,515 & 10,216 & 10,195 \\
\hline Texas State University & 5 & 3,716 & 4,065 & 3,951 & 5,041 & 5,647 & 5,936 & 6,237 & 6,345 & 6,263 & 5,983 & 6,728 & 7,237 & 7,690 & 8,038 \\
\hline Texas Tech University & 5 & 5,481 & 5,561 & 6,238 & 6,504 & 6,966 & 7,179 & 7,044 & 7,715 & 8,418 & 8,693 & 8,919 & 8,792 & 9,168 & 9,360 \\
\hline
\end{tabular}




\begin{tabular}{|c|c|c|c|c|c|c|c|c|c|c|c|c|c|c|c|}
\hline The University of Texas at Arlington & 5 & 3,406 & 4,704 & 4,892 & 5,631 & 6,330 & 6,682 & 6,932 & 6,468 & 6,796 & 7,520 & 7,034 & 7,387 & 6,903 & 7,664 \\
\hline The University of Texas at Austin & 5 & 5,186 & 5,715 & 6,494 & 7,283 & 7,991 & 8,372 & 8,900 & 9,402 & 9,898 & 10,164 & 10,476 & 10,165 & 10,243 & 10,364 \\
\hline The University of Texas at Dallas & 5 & 3,597 & 4,952 & 5,435 & 5,756 & 6,959 & 7,483 & 8,345 & 8,993 & 9,834 & 9,373 & 10,335 & 10,462 & 11,382 & 11,442 \\
\hline The University of Texas at El Paso & 5 & 2,515 & 3,306 & 3,437 & 4,203 & 4,596 & 4,843 & 5,255 & 5,230 & 5,383 & 5,595 & 4,743 & 5,661 & 5,952 & 5,837 \\
\hline The University of Texas at San & 5 & 3,274 & 4,337 & 4,765 & 5,401 & 6,316 & 6,451 & 6,970 & 7,091 & 6,956 & 7,476 & 7,114 & 7,653 & 7,944 & 7,548 \\
\hline \multicolumn{16}{|l|}{ Antonio } \\
\hline The University of Texas Rio Grande & 5 & 1,840 & 2,066 & 2,203 & 2,470 & 2,710 & 3,204 & 3,231 & 3,043 & 3,117 & 3,625 & 3,951 & 3,941 & 3,168 & 4,255 \\
\hline \multicolumn{16}{|l|}{ Valley } \\
\hline University of Houston & 5 & 4,536 & 5,339 & 5,446 & 6,118 & 7,350 & 7,789 & 7,836 & 7,582 & 8,486 & 9,716 & 9,305 & 9,891 & 10,08 & 10,374 \\
\hline
\end{tabular}




\section{RESULTS}

The findings of this study suggest cuts to public higher education state funding is affected more prominently during times of a recession, and that in many states, the funding of public higher education does not return to pre-recession amounts (Flores \& Shepard, 2014). This leads to higher costs for higher education, which affects access for all, as well as causing concern for the ability to have a skilled and educated workforce and an economy that is strong and competitive (Delisle \& Copper, 2018). State cuts to higher education impact the economy, and a more balanced mix of spending cuts and revenue increases by the legislature could lessen the need for higher education cuts (Ford, 2017). Whether or not there is a significant correlation between decreased state appropriations and increased tuition and fees, the continued increase in tuition reduces academic opportunities, often compromises the quality of education, and jeopardizes student success (Delisle, 2018; Kim \& Ko 2014; Mitchell, Leachman, Masterson, \& Waxman, 2018). For the state to sustain an investment in the public higher education system and promote college affordability and quality, those involved in budget decisions must recognize the importance of investment in human capital, and the need for quality education for an enriched society (Mitchell, Leachman, \& Masterson, 2017; Mitchell et al., 2018).

Findings from this study showed no evidence of a correlation existing between the decrease in state appropriations and the increase of Texas public higher education institution tuition costs, when the analysis reviewed the timeframe from fiscal years 2003 to 2016 . Though no evidence exists for this correlation, it implies that other factors explain why colleges raise their tuition prices, and that larger allocations may not alleviate the price increase. It is intended that the results of this study will inform policymakers and Texas public higher education institutions that though correlations are not presented, it can be used to refine the allocation process to offer more balance between state initiatives and higher education.

The findings of this study lead to several implications for higher education practice. The first implication is the need to reevaluate the external factors influencing the dramatically reduced state budgets and the continuing increase of tuition rates in Texas public higher education institutions. The decline in state allocations in Texas from the Great Recession (20072009) coupled with the deregulation of tuition set the state for significant increases in tuition rates. This increase in tuition and decrease in state support has influenced the affordability and attainment of higher education. The second implication for higher education is that deregulation of tuition may not be the exclusive factor in the escalation of tuition and fees charged by public higher education institutions. The relationship between state appropriations and higher education institution tuition rates may be a result of external factors heavily influencing the balance of this partnership. The third implication for practice in higher education is the weak support of the state to higher education institutions. The disinvestment of the state towards higher education causes higher education to reduce programs or course offerings in 
order to maintain with the given budget. This calls for a renewed investment in higher education to help institutions to remain competitive and relevant.

In addition, based on the findings of this study recommendations for higher education practice would be transparency with regard to budgetary process between governing powers, such as the Texas Higher Education Coordinating Board, policymakers, and higher education institutions. When making appropriation decisions, it is important for transparency in order to provide and maintain a sustainable and balanced budget for both the institutions and the state. A second recommendation would be rational approach to tuition payment processes for affordability and attainment. Through a process of budget review, alterations can be made to work toward a tuition setting process by governing boards and institutions to identify and reduce the financial burden to the students and encourage degree completion in a condensed time based on a tuition reduction.

\section{Implications for Higher Education Practice}

The findings of this study have resulted in three implications for higher education practice. The first implication for higher education practice based on the findings of this study is that as state funding decreases and the economy is in a downturn, the costs of higher education will rise. The decline in state funding allocations in Texas resulting from the Great Recession, combined with tuition deregulation in 2003, set the stage for significant increases in tuition rates exceeding the rate of inflation. The cuts in state funding of public higher education were extensive during the Great Recession, and the funding allocations have not recovered since the end of this recession in 2009. This is partly reflected in the decisions made by legislators to rely overwhelmingly on spending cuts rather than revenue increases to make up for the lost state revenue (Mitchell, Leachman, \& Masterson, 2017).

The second implication for higher education practice is that deregulation of tuition may not be the main driver of escalating tuition and fees charged by public higher education institutions. Other studies such as Delisle (2017), Ford (2017) and Nemser and Whitener (2018) describe how state disinvestment in higher education has reduced the FTE student appropriations over time to public four-year institutions, especially during economic recessions. However, the existence of a causal relationship between state appropriations and tuition at public institutions is often asserted, without any statistical evidence. Kim and Ko (2014) found that changes in state appropriations have little effect on tuition at public institutions. Rizzo and Ehrenberg (2004) found the magnitude of the effect of reduction in state appropriations on tuition is insignificant. The strength of the relationship between state appropriations and tuition has important implications for policy debates (Delisle \& Copper, 2018) such as strengthening partnerships between state-university and governing bodies for deregulation reform initiatives (Li, 2017). If the relationship between state appropriations and increased tuition costs at public institutions proves weak, then the common claim of cuts to funding by the state are the "primary driver" of changes in tuition will find little support (Mitchell et al. para. 5, 2018). 
The third implication for higher education practice is that even if the relationship between state appropriations and tuition proves weak, declining or flat state support for higher education is still a concern. Institutions of higher education must still account for increases in their costs due to inflation (Delisle, 2017). Furthermore, state funding levels have not kept up with enrollment growth. The Great Recession economic downturn drastically reduced state budgets, including state funding for higher education (Nemser \& Whitener, 2018). Following other historical economic downturns, higher education eventually regained the state funding it lost during the recession, but this has not been the case in all U.S. states after the Great Recession (Delisle \& Copper, 2018). As of 2018, only six states (Hawaii, Washington, Idaho, California, New Hampshire, and Oregon) had returned higher education funding back to the prerecession levels (Gunn, 2018). In 2017, for 19 states the state's expenditures per FTE student were at least $20 \%$ lower than they were before the recession (State Higher Education Executive Officers Association [SHEEO], 2017). As a result, a call for renewed investment in higher education is necessary for institutions to remain competitive and relevant (Selingo, 2018).

\section{Recommendations for Future Research}

Based on the findings of this study, the following are recommendations for future research. The first recommendation is while Texas public four-year higher education institutions functioned in a period of flat-to-moderate increases in overall state support, other state policy environments have not shown increases (Toppo, 2019). A state with a relatively large number of public higher education institutions having experienced absolute budgetary reductions and lower growth per real FTE student would provide an interesting counterpoint to this study, as it would assess disbursement verdicts made to distribute decreases rather than to allocate extra funding. In particular, an evaluation of graduate education and the rest of the institution in that environment would be interesting. A qualitative collective case study that focuses on the institutional budgets from the perspective of the governing boards along with the tuition and fees rates per FTE student enrollment would pose a different perspective of the correlation between decreased state appropriations and increased tuition and fees with the same fiscal years of FY2003 to FY2016.

Another recommended study would be to conduct an analysis similar to this study for the private not-for-profit institutions replacing state appropriations received per full-time student with endowment income per full-time student. In particular, it would be assumed institutions with generous endowment income could be in a position to offer tuition relief or possibly grants to students based on merit. It is possible a stronger correlation between endowment income and institutional aid exists than what might be found in this study between state appropriations and tuition costs. With such a study, it should note the distinction between listed tuition rates and what students are actually required to pay. A study analyzing this for private not-for-profit higher education would be an interesting contribution to the literature. 


\section{CONCLUSION}

The purpose of this study was to examine the relationship between state appropriation decreases and the tuition cost increases in Texas four-year, public higher education institutions. Findings for this study did not offer a very strong relationship between the state appropriation decreases and tuition costs; however, policymakers and institutional governing boards should consider realignment to provide adequate funding processes for education as well as state initiatives.

The practical implications of this study may assist policymakers, Texas public higher education institutions and the Texas Higher Education Coordinating Board who are evaluating, developing, and implementing the funding process. Although, there is no evidence suggested in the correlation between the decrease in state appropriations and the increase in tuition costs during the timeframe of 2003 to 2016, the allocations process continues to be a challenging process. It is intended that the results of this study will inform policymakers and Texas public higher education institutions that though correlations are not presented, it can be used to refine the allocation process to offer more balance between state initiatives and higher education.

\section{REFERENCES}

Alves, H. (2011). The measurement of perceived value in higher education: A unidimensional approach. The Service Industries Journal, 31(12), 1943-1960.

Ames, W. (2014). Numerical Methods for partial differential equations. San Diego, CA: Academic Press, Inc.

Barr, M. J., \& McCellan, G. S. (2011). Budgets and financial management in higher education. San Francisco, CA: John Wiley \& Sons, Inc.

Bastedo, M. N., Altbach, P. G., \& Gumport, P. J. (2016). American higher education in the twenty-first century: Social, political, and economic challenges. Baltimore, MD: Johns Hopkins University Press.

Baum, S., Harris, D. N., Kelly, A., \& Mitchell, T. (2017, September). A principled federal role in higher education. Urban Institute. Retrieved from https://files.eric.ed.gov/fulltext/ED578885.pdf

Bound, J., Braga, B., Khanna, G., \& Turner, S. (2016). A passage to America: University funding and international students. (Working Paper) National Bureau of Economic Research. Retrieved from https://www.nber.org/papers/w22981.pdf

Cardona, C. (2012, September). Texas college tuition up 55\% since 2003 deregulation, analysis shows. Dallas Morning News. Retrieved from

https://www.dallasnews.com/news/texas/2012/09/22/texas-college-tuition-up-55since-2003-deregulation-analysis-shows

College Board (2016). Trends in college pricing 2016. The College Board Trends in Higher Education Series. Retrieved from 
https://trends.collegeboard.org/sites/default/files/2016-trends-college-pricingweb_0.pdf

Conner, T. W., \& Rabvsky, T. M. (2011). Accountability, affordability, access: A review of the recent trends in higher education policy research. (Essay). Policy Studies Journal, (1), S93. Retrieved from https://easydb.angelo.edu/login?url=http://search.ebscohost.com /login.aspx?direct=true\&db=edsgit\&AN=edsgit.A253322312\&site=eds-live

Cooper, P. (2017, June 7). Pennies on the Dollar: The surprisingly week relationship between state subsidies and college tuition. American Enterprise Institute. Retrieved from http://www.aei.org/publication/pennies-on-the-dollar-the-surprisingly-weakrelationship-between-state-subsidies-and-college-tuition/

Delaney, J. A. (2014). The role of state policy in promoting college affordability. Annals of the American Academy of Political and Social Science, 655, 56-78.

Delaney, J. A., \& Kearney, T. D. (2015). Guaranteed tuition policies and state general appropriations for higher education: A difference-in-difference analysis. The Journal of Education Finance, 40(4), 359-391.

Dickeson, R. (2006). Frequently asked questions about college costs. The Secretary of Education's Commission on the Future of Higher Education. Retrieved from https://www2.ed.gov/about/bdscomm/list/hiedfuture/reports/dickeson2.pdf

Dolan, M. (2015, April 21). Tuition deregulation places unnecessary burden on students. The Daily Texan. Retrieved from http://www.dailytexanonline.com/2015/04/21/tuitionderegulation-places-unnecessary-burden-on-students

Dougherty, K. J., \& Reddy, V. (2011, December). The impacts of state performance funding systems on higher education institutions: Research literature review and policy recommendations. (Working paper, No. 37). Community College Research Center. Retrieved from http://files.eric.ed.gov/fulltext/ED527751.pdf

Edwards, C., \& McCluskey, N. (2015, November 1). Higher education subsidies. Downsizing the federal government. Retrieved from https://www.downsizing government.org/ education/higher-education-subsidies

Epple, D., Romano, R., Sarpca, S., Sieg, H., \& Zaber, M. (2019). Market power and price discrimination in the U.S. market for higher education. RAND Journal of Economics, 50(1), 201-225. Retrieved from http://humcap.uchicago.edu/RePEc/ hka/wpaper/Epple_Romano_etal_2017_market-power.pdf

Executive Summary (2012). Formula funding recommendations 2012. Retrieved from http://www.thecb.state.tx.us/files/dmfile/BOP20102011.pdf

Finney, J. E. (2016). College affordability diagnosis: National report. Institute for Research on Higher Education, Graduate School of Education, University of Pennsylvania. Retrieved from https://www2.gse.upenn.edu/irhe/sites.gse. upenn.edu.irhe/files/ Natl_Affordability.pdf 
Flores, S. M., \& Shepherd, J. C. (2014, September). Pricing out the Disadvantaged? The effect of tuition deregulation in Texas public four-year institutions. The American Academy of Political and Social Science, 99(655). Retrieved from

http://wwwlexisnexiscom.libe2.lib.ttu.edu/hottopics/Inacademic/?verb=sr\&csi=165641 \&sr=TITLE $(T H E+R O L E+O F+S T A T E+P O L I C Y+I N+P R O M O T I N G+C O L L E G E+A C C E S S+A N D+S U$ CCESS+SPECIAL+EDITORS+LAURA+W.+PERNA+AND+MICHAEL+K.+MCLENDON+Pricing+ Out+the+Disadvantaged\%3F+The+Effect+of+Tuition+Deregulation+in+Texas+Public+Fo ur-Year+Institutions)\%2BAND\%2BDATE\%2BIS\%2B2014

Gale, W. G., Krupkin, A., \& Rueben, K. (2015). The relationship between taxes and growth at the state level: New evidence. National Tax Journal, 68(4). Retrieved from http://dx.doi.org/10.17310/nj.2015.4.02

Gunn, D. (2018, October 4). State spending on higher education still hasn't recovered from the recession and progress on that front may be slowing. Pacific Standard. Retrieved from https://psmag.com/education/state-spending-on-higher-education-still-hasntrecovered-from-the-recession

Hart, P. (2005, February). (Much) Higher education: Does tuition deregulation mean that UT and A\&M cost too much? It's a matter of degrees. Texas Monthly. Retrieved from https://www.texasmonthly.com/articles/much-higher-education/

Hensley, D. (2015). Texas' six chancellors of public higher education join forces in advance of legislative session. Retrieved from http://www.texastech.edu/stories/ 15-01-texas-sixchancellors -of-public-higher-education-join-forces-in-advance-oflegislative-session.php Helmcamp, L. (2012, August 12). Texas' investment in higher education lags behind student needs and workforce demands. Demos. Retrieved from http://www.demos.org/publication/texas\%E2\%80\%99-investment-higher-educationlags-behind-student-needs-and-workforce-demands

Hernandez, J. C. (2009). Student price response: The effect of tuition deregulation in Texas on student enrollment trends in Texas public institutions of higher education. Dissertation Abstracts International Section A, 70, 1497.

Hillman, N. W, Tandberg, D. A., \& Gross, J. P. K. (2014). Performance funding in higher education: Do financial incentives impact college completions? The Journal of Higher Education 85(6), 826-857.

Hung, D. (2015, January 25). Tuition increases must have limits. The Daily Texan. Retrieved from http://www.dailytexanonline.com/2015/01/25/tuition-increases-must-have-limits Johnstone, D. B. (2005). The economics and politics of cost sharing in higher education: Comparative perspectives. Economics of Education Review, 23(4), 403-410.

Kasriel, S. (2017 December). 4 predictions for the future of work. World Economic Forum. Retrieved from https://www.weforum.org/agenda/2017/12/predictions-for-freelancework-education/ 
Kim, M. M., \& Ko, J. (2015). The impacts of state control policies on college tuition increase. Educational Policy, 29(5), 815-838. Retrieved from https://journals-sagepubcom.easydb.angelo.edu/doi/pdf/10.1177/0895904813518100

Kim, J., \& Stange, K. (2016). Pricing and university autonomy: Tuition deregulation in Texas. RSF: The Russel Sage Foundation Journal of the Social Sciences, (1), 112.

Li, A. (2017). Dramatic Declines in Higher Education Appropriations: State Conditions for Budget Punctuations. Research in Higher Education, 58(4), 395-429. https://doiorg.easydb.angelo.edu/10.1007/s11162-016-9432-0

Lucas, C. J. (1994). American higher Education: A history. New York, New York: Library of Congress.

McBain, L. (2010, May). Tuition-setting authority and deregulation at state colleges and universities. American Association of State Colleges and Universities: A Higher Education Policy Brief. Retrieved from http://www.aascu.org/policy/ publications/policy-matters/2010/tuitionsettingauthority.pdf

McBain, L. (2010, May). Tuition-setting authority and deregulation at state colleges and universities. American Association of State Colleges and Universities: A Higher Education Policy Brief. Retrieved from http://www.aascu.org/policy/publications/policymatters/2010/tuitionsettingauthority.pdf

McCluskey, N. (2015). Most college cost fixes miss the root of the problem. CATO Institute. Retrieved from https://www.cato.org/publications/testimony/most-college-cost-fixesmiss-root-problem

McLendon, M. K., Jearn, J. C., \& Mokher, C. G. (2009). Partisans, professionals, and power: The role of political factors in state higher education. The Journal of Higher Education, 80(6), pp. 686-713. doi: https://doi.org/10/1352/jhe.0.0075

McPherson, P., \& Shulenburger, D. (2008). University tuition, consumer choice and college affordability: Strategies for addressing a higher education affordability challenge. National Association of Universities and Land-Grant Colleges, 1-87. Retrieved from https://kuscholarworks.ku.edu/bitstream/handle/1808/12507

Shulenburger_University.pdf?sequence=1\&isAllowed=y

Megan, K. \& Varn, J. (2017, January 19). Rising college tuition: Are states to blame? Bipartisan Policy Center. Retrieved from https://bipartisanpolicy.org/blog/rising-college-tuitionare-states-to-blame/\#

Mitchell, M., Leachman, M., \& Masterson, K. (2016, August 15). Funding down, tuition up: State cuts to higher education threaten quality and affordability at public colleges. Center on Budget and Policy Priorities. Retrieved from http://www.aascu.org/policy/publication s/policymatters/2010/tuitionsettingauthority.pdf 
Mitchell, M., Leachman, M., \& Masterson, K. (2017, August 23). A lost decade in higher education funding: State cuts have driven up tuition and reduced quality. Center on Budget and Policy Priorities. Retrieved from https://www.cbpp.org/research/statebudget-and-tax/a-lost-decade-in-higher-education-funding

Mitchell, M., Leachman, M., Masterson, K., Waxman, S. (2018, October 4). Unkept promises: State cuts to higher education threaten access and equity. Center on Budget and Policy Priorities. Retrieved from https://www.cbpp.org/research/state-budget-andtax/unkept-promises-state-cuts-to-higher-education-threaten-access-and-equity National Center for Education Statistics. (2016). About NPSAS. Retrieved from https://nces.ed.gov/surveys/npsas/about.asp

National Center for Education Statistics. (2016). 2015-2016 Integrated postsecondary education data system (IPEDS) methodology report. Retrieved from https://nces.ed.gov.pubs2016111.pdf

National Center for Education Statistics. (2016). Tuition costs of colleges and universities.

Digest of Education Statistics. Retrieved from https://nces.ed.gov/fastfacts/ display .asp?id=76

National Commission on the Cost of Higher Education (2013). Institutional eligibility under the Higher Education Act of 1965, as amended. Federal Register, 78(98). Retrieved from https://www.govinfo.gov/content/pkg/FR-2013-05-21/pdf/2013-12087.pdf

Nemser, D. \& Whitener, B. (2018, March 26). The tuition limit and the coming crisis of higher education: What happens to higher education when universities can no longer hike tuition?. The New Inquiry. Retrieved from https://thenewinquirty.com /the-tuitionlimit-and-the-coming-crisis-of-higher-education/

Page, L.C., \& Scott-Clayton, J. (2016). Improving college access in the United States: Barriers and policy responses. Economics of Education, 5, 4-22.

Rothstein, J., \& Rouse, C. E. (2011). Constrained after college: Student loans and early-career occupational choices. Journal of Public Economics, 95, 149-163.

Russell, J., \& Markel, R. (2015). Continuing a culture of evidence: Assessment for improvement. Educational Testing Service. Princeton, NJ. Doi:10.1002/ets2.12136

Schwertner, C. (2014, December 7). Tuition deregulation is failing Texas students. Texas Tribune. Retrieved from https://www.tribtalk.org/2014/12/07/tuition-deregulation-isfailing-texas-students/

Tandberg, D. A., \& Laderman, S. A. (2018, June). Evaluating state funding effort for higher education. Midwestern Higher Education Compact. Retrieved from https://files.eric.ed.gov/fulltext/ED587428.pdf

Tex. Educ. Code $\S 54.051$

Tex. Educ. Code $\S 54.0513$

Texas Higher Education Coordinating Board (THECB) (n.d.). Higher education data. Retrieved from http://www.thecb.state.tx.us/files/dmfile 
Texas Higher Education Coordinating Board (n.d.) Division of Planning and Accountability. Retrieved from http://www.txhigheredaccountability.org/AcctPublic/Resources/ History

Texas Higher Education Coordinating Board (2008). General Appropriations Act Overview 2008-2009 Biennium Report. Retrieved from http://www.thecb.state.tx.us/index.cfm?objectid=503AE0CA-E26B-77E7989C9C76FB7AC934

Texas Higher Education Coordinating Board (2015). Division of Strategic Planning and Funding. Formula funding recommendations for the 2018-2019 Biennium. Retrieved from http://www.thecb.state.tx.us/reports/PDF/7531.PDF?CFID=66909350\&CFTOKEN $=41117088$

Texas Higher Education Coordinating Board (2017). General Appropriations Act Overview 2010-2011 through 2016-2017. Retrieved from http://www.thecb.state.tx.us/ index.cfm?objectid=503AE0CA-E26B-77E7-989C9C76FB7AC934

Texas Legislative Budget Board, Legislative Policy Report (2011). Financing higher education in Texas. Retrieved from http://www.Ibb.state.tx.us/Documents/Publications/Policy _Report/

Texas Legislative Budget Board, Legislative Policy Report (2011). Texas public education: Overview of tuition and state support since tuition deregulation. Retrieved from http://www.lbb.state.tx.us/Documents/Publications/Presentation/1979_Presentation_ Overview_Tuition_State_Support_April_2016.pdf

Texas Legislature. State of Texas Appropriations Bill. House Bill 1, Eightieth Legislature Regular Session. Retrieved from Texas Legislature Online:

http://www.capitol.state.tx.us./BillLookup/History.aspx?LegSess

Texas Legislature. State of Texas Appropriations Bill. House Bill 1, Eightieth Legislature Regular Session. Retrieved from Texas Legislature Online:

http://www.capitol.state.tx.us./BillLookup/History.aspx?LegSess

Texas Legislature. State of Texas Appropriations Bill. House Bill 1, Eighty-fourth Legislature Regular Session. Retrieved from Texas Legislature Online: http://www.capitol.state.tx.us./BillLookup/History.aspx?LegSess

Texas Legislature. General Appropriations Act for the 2016-2017 Biennium, House Bill 1, Eightfourth Texas Legislature Regular Session. Retrieved from http://www.lbb.state.tx.us/Documents/GAA/General_Appropriations_Act_20162017.pdf

Titus, M. A. (2009). The production of bachelor's degrees and financial aspects of state higher education policy: A dynamic analysis. The Journal of Higher Education, 80(4), 439-468.

Toppo, G. (2019, January 21). 'A marginally better year' for state funding. Inside Higher Ed. Retrieved from https://www.insidehighered.com/news/2019/01/21/state-supporthigher-ed-rises-37-percent-improves-over-2017 
Toutkoushian, R. K., \& Paulsen, M. B. (2009). Economics of higher education: Background, concepts, and applications. New York, New York: Springer.

Toutkoushian, R. K., \& Shafiq, M. N. (2009). A conceptual analysis of state support for higher education: Appropriations versus need-based financial aid. Research in Higher Education, 51(1), 40-64.

United States Department of Education (n.d.). College affordability and completion: Ensuring a pathway to opportunity. Retrieved from https://www.ed.gov/college

United States Department of Education (n.d.). National center for education statistics (NCES) goals. Retrieved from http://www.ed.gov/open/plan/nces

Watkins, M., \& Daniels, A. (2017, February 7). Texas families are struggling to pay for collegebut so is the state. The Texas Tribune. Retrieved from https://www.texastribune.org/2017/06/22/ballpark-figures-texas-m-reigns-uh-getsboost-texas-college-sports-rev/

Weeden, D. (2015, September 20). Tuition policy. National Conference of State Legislatures. Retrieved from http://www.ncsl.org/research/education/tuition-policy.aspx

Weerts, D. J., \& Ronca, J. M. (2012). Understanding differences in state support for higher education across states, sectors, and institutions: A longitudinal study. The Journal of Higher Education, 82(2), 155-185. doi: 10.1353/jhe.2012.0012 